\title{
PSYCHOSOMATIC TENDENCIES, COPING STYLES AND LOCUS OF CONTROL AMONG YOUNG ADULTS
}

\author{
Melis Bilibani $^{1}$, Emilija Stoimenova Canevska ${ }^{1}$, Nada Pop-Jordanova ${ }^{2}$
}

\author{
${ }^{1}$ International Balkan University, Skopje, R. N. Macedonia \\ ${ }^{2}$ Macedonian Academy of Sciences and Arts, Skopje, R. N. Macedonia
}

Corresponding author: Nada Pop-Jordanova, Bul Krste Misirkov br.2, P.O.Box 428, 1000 Skopje, North Macedonia, e-mail: popjordanova.nadica@gmail.com

\section{ABSTRACT}

It is really difficult to live in a society in which the human contact is decreasing each day, and where stressful situations become unavoidable. In order to be healthy and have a healthy lifestyle, the coping style plays a huge role.

Witnessing this situation every day, the aim of this research is to investigate the connection among psychosomatic tendencies, different coping styles and locus of control in young adults, aged from 24 to 34 years, in the Republic of North Macedonia.

The evaluated sample consists of $187(\mathrm{M}=47 ; \mathrm{F}=140)$ participants, randomly selected, who accepted to be the part of the research by filling in the on-line questionnaires, delivered through Google forms. The short demographic questionnaire and three psychological instruments were used: Cybernetic Battery of Conjunctive tests KON-6, CISS-21 (Coping Inventory for Stressful Situations), and Internal-External Locus of Control Scale (I-E).

Spearman's correlation was used in order to check and approve the connectedness among psychosomatic tendencies, coping styles and locus of control.

The obtained results confirm that there is a significant correlation among tendencies towards psychosomatic reaction, coping styles and locus of control among young adults in the Republic of North Macedonia.

Keywords: psychosomatic symptoms, coping, stress, locus of control, young adults

\section{INTRODUCTION}

The contemporary society is characterized by fast technological and industrial development. This society easily turns from collectivistic into individualistic tendencies, where the exposure to stress is raising every day, and where people are prone to a declining of the help and support from the loved ones. This achievement-oriented society consists of youngsters and young adults that are constantly under the pressure to succeed. Besides these problems, society is also faced with the lack of employment, poverty, inequality and climate changes. Life without stress is unfortunately, unimaginable.

Additionally, with the arrival of the digital era and the use of high amount of social media, the 
human connection is decreasing each and every day. Since the human connection is essential for survival, the lack of it may have significant impact on one's health and well-being. It is known that the lack of social support leads to increased risk for developing a mental illness.

Consequently, individuals pay a high price to live in the system of 21 st century.

The outcome of today's way of living is manifested in numerous anxious and panic attacks, chronical fatigue, allergic reactions, cardiovascular diseases and other types of psychosomatic symptoms and psychosomatic illnesses. The chronical stress, as well as the everyday stressful events lead to unwanted consequences on both, the human body and the psyche. Our beliefs are leading us toward adverse reactions in our body, no matter who is in charge, the person involved or the strong influences from the outside.

The aim of this research is to investigate the connection among psychosomatic tendencies, different coping styles and the locus of control in young adults, aged from 24 to 34 years, in the Republic of North Macedonia. Keeping in mind all the changes in the world in the past few decades, individuals in this period of their life are faced with the highest amount of stress. Also, the necessity to point on locus of control, coping styles and psychosomatics more in depth, as well as their correlations, lies in their high influence to the healthy functioning of individuals in the contemporary world.

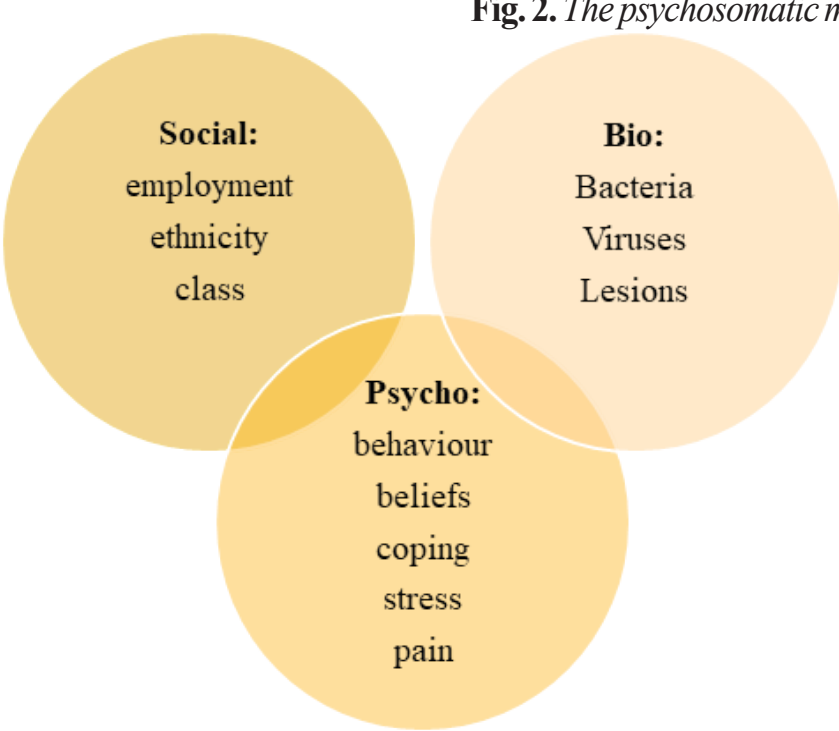

Fig. 3. The biopsychosocial model of health and illness (Engel 1980, as cited in Ogden, 2007: 4)

Combining Adler's theory of inferiority of a child (Ewen, 2003) and Cannon's "fight and flight" theory, Freud's student Franz Alexander believed that there is a connection between specific illnesses and chronic repressed emotions. He also believed that an illness is not caused by the repressed emotion, instead, it is caused by the chronic activation or stimulation of a specific vegetative organ, until it loses its healthy way of functioning. Franz Alexander sorted out seven psychosomatic illnesses and named them as "holy seven": Bronchial asthma, Peptic ulcer, Ulcerative colitis, Thyrotoxicosis, Essential hypertension, Rheumatoid arthritis, Neurodermatitis (Harrington, 2008). Contemporary psychologist Adamovic (2005) adds ten more illnesses to this group: Coronary disease, Diabetes mellitus, Herpes simplex, zoster and genitalis, Hyperinsulinismus, Hypoglycemia, Obesity, Regional enteritis, Tuberculosis, Anorexia nervosa and Bulimia nervosa.

It is well known, that there is more than one factor contributing to the pathogenesis of an illness: genes, genetic changes, environmental factors, the accumulation of the life events, early emotional trauma, ecological factors, lifestyle and factor "X", described as the predisposition factor. Taking these into consideration, Adamovic (1983) has pointed on the difference among medical model (Figure 1) and psychosomatic model (Figure 2) of illness.

external cause $\rightarrow$ somatic damage $\rightarrow$ disturbed function $\rightarrow$ somatic symptom

Fig. 1. The medical model of illness (Adamovic, 1983)

psychological disorder $\rightarrow$ disturbed function $\rightarrow$ tissue damage $\rightarrow$ somatic symptom

Fig. 2. The psychosomatic model of illness (Adamovic, 1983) 
In this context, Lipowski defined specifics of psychosomatic medicine as:

- Scientific discipline that is determining the illness or health of an individual through the biological, psychological and social factors,

- Holistic approach in the medical practice,

- Consultative psychiatry.

According to ICD-10, psychosomatic disorders are under the 'Somatoform disorders' category (F45) characterized by physical symptoms and persistent requests for medical assistance and often a histrionic behaviour. Most recently published, ICD-11, has changed the name of the "Somatoform Disorders" into "Bodily Distress Disorder" and it is more similar to DSM-5, rather than ICD 10.

The topic of stress has come up to the light in the past 70 years and the psychologists have not had an easy time coming up with the right and acceptable definition for it. As a concept it was mentioned around 400 B.C. by Hippocrates, who differentiated among symptoms that are caused by the illness (pathos) and the ones caused as the body fights to hold out against the illness (ponos) (Straub, 2002).

One of the earliest models of stress was developed by Cannon in 1932, and he called it Fightor-Flight Model of Stress. He suggested that when an individual was faced with an external threat, the individual would get highly aroused, which would enable one to fight the threat or escape from the situation. Cannon believed that an individual could manage the stressful situation in the adaptive way. However, if the stress was prolonged, it could cause some medical problems (Ogden, 2007). Some contemporary researchers besides fight and flight, mention the freeze response to the fear, which manifests as a very passive form of avoidance (Maack, Buchanan, \& Young, 2015).

Contemporary views of stress rely on the work of Lazarus and Folkman in 1986. This model has its roots in the previous works of Lazarus. Namely, when Lazarus and Launier in 1978, described stress as the transaction or relation among individuals and their environment, they described stress in the sense as 'person-environment fit'. They explained that when an individual is faced with the potential stress, the first thing the person is faced with is the perception, or the appraisal of the situation. After the appraisal of the situation, check process of possession of necessary "skills" to deal with the situation, follows. The individual with the positive person-environment fit experiences low levels of stress, whereas other with a poor-fit experiences high levels of stress (Ogden, 2007).
Coping refers to the cognitive, behavioural, and emotional ways that people manage stressful situations (as cited in Straub, 2002: 166). It is not a one-time reaction, in contrary, it is a process that involves the interaction of the person with their environment, considered as an attempt to preserve both physical and mental health. Coping is also defined as an effort to deal with the harmful situation, to remove threat, or reduce the negative impact on the individual (Friedman \& Silver, 2007).

Since everyone has their own way of coping with stress, many authors have attempted to differentiate among various coping styles. They have introduced the following coping styles: emotion-focused coping, problem-focused coping, avoidant coping, positive, meaning-focused and spiritual coping, preventive or proactive coping, and so on.

The concept of locus of control was developed and introduced by Julian Rotter as a major concept in his social learning theory. Through one's social experiences and interactions with the others, one creates an image and values certain goals for which anticipates to reach. In this context, the word 'anticipate' means that individuals learn that through certain fashion of behaviour they will obtain either reward or punishment, which is regarded as a reinforcement. Since individuals are driven to meet certain needs, they will increase the actions that support one in meeting those needs. In other words, "reinforcement" was used so the action could be repeated in the future. In order to evaluate the real impact of the reinforcement, Rotter emphasized that the connection among the behaviour and reinforcement should be acknowledged. If the individual acknowledges the connection among the behaviour and the reinforcement, one would learn that if they behave in the similar way next time, the reward will most likely occur. However, if the connection is not acknowledged, the reward will be considered as luck. Being capable to see the connection among the behaviour and its consequence is called contingent reinforcement, and it is a key element in the process of the awareness of the internal control and the extent to which individual is responsible for the outcome of the certain behaviour (Nowicki, 2016; Rotter, 1966). It is essential to mention that locus of control changes with age, it is not static. As one grows, mental and physical abilities increase, therefore one gets the awareness of personal control over some situations. The older one tends more to internalize locus of control (Nowicki, 2016). 


\section{METHOD AND SAMPLE}

The participants involved in this research are young adults from the Republic of North Macedonia. The age-range of the participants is from 24 years to 34 years. That is defining them as young adults according to Erik Erikson's theory of psychosocial development (Newman \& Newman, 2012).

The sample consisted of 187 participants that accepted to fill in the online questionnaire, during May 2019. The highest number of the participants that were involved in the research were females and individuals from 24 to 26 years.

For the purpose of this research, we have used three different psychological instruments: HI test from Cybernetic Battery of Conjunctive tests KON-6, CISS-21 (Coping Inventory for Stressful Situations), Internal-External Locus of Control Scale (I-E), and short demographic questionnaire.

In order to measure the tendencies towards psychosomatic symptoms, we used the HI test from Cybernetic Battery of Conjunctive tests KON-6 constructed by Momirovic \& Dzamonja (Momirovic, Wolf, \& Dzamonija, 1992). It measures the efficacy of the self-regulation system and the control of cellular functions. Composed of 30 items, it does not have any inversely keyed items. Items are posed on a 5-point Likert scale from ++ until -, in which ++ means "I totally agree" and - "I totally disagree". Results are gathered by summing up the results from the 5-point Likert scale. The lowest result is 30 , pointing on the low tendencies for psychosomatic symptoms, whereas highest result is 150 and points on very high tendencies for psychosomatic symptoms. Therefore, the operational definition for tendencies towards psychosomatic reaction will be as follows: participants who have results around 30, have low tendencies towards psychosomatic reaction, whereas participants who have results around 150 have high tendencies towards psychosomatic reactions. The higher the results, the higher the tendency towards psychosomatic reactions. In order to measure the internal consistency, we used the Cronbach's Alpha coefficient, which is very high $(\alpha=0.916)$.

To measure coping styles, we used the short version of CISS-21, (Coping Inventory for Stressful Situations) developed by Endler and Parker (Endler, \& Parker, 1990). Composed of three different scales: problem-oriented coping, emotion-oriented coping and avoidant coping scale, the inventory has 21 item and none of them is inversely keyed. Items are posed on the 5-point Likert scale, from 1 to 5, where 1 represents "I never do this" and 5 represents "I usually do this". Each scale has seven items and the results are calculated by summing up the results. High score denotes the high prevalence of particular coping style, whereas the low score denotes low prevalence. The operational definition for coping styles will be, if the results of a particular scale are higher, that particular coping style is prevalent in an individual, if the score is low, the particular coping style is not prevalent. For this test we have performed the Cronbach's Alpha coefficient, in order to check its internal consistency for this sample. The results are as following: the coefficient for the entire inventory is $\alpha=0.635$, the coefficient for the problem-focused coping scale is $\alpha=0.736$, the coefficient for the emotion-focused coping scale is $\alpha=0.799$, and the coefficient for the avoidant coping scale is $\alpha=0.648$. From these results we can conclude that the internal consistency of the inventory itself and the scales separately, is around what is considered to be approved or significant reliability and internal consistency.

For measuring the locus of control, we used the Internal-External Locus of Control Scale (IE) that was developed by Julian Rotter (Rotter's Locus of Control Scale; Rotter, 1966). The test measures the tendency of individuals to prescribe the consequences of certain events to themselves or to some external factors. The test consists of 29 items that have two options for answering, out of which one has to be chosen. The score is calculated by summing up the results that are given in the manual. High score determines external locus of control, whereas low score determines internal locus of control. Therefore, the operational definition for the locus of control is: the higher the result, the more prevalent is the external locus of control and vice versa. In order to check the reliability and internal consistency of this test for this sample we have used the Cronbach's Alpha coefficient. The coefficient for this test was $\alpha=0.591$, which was very low. Therefore, we performed the reliability testing on the items. We have found out that items overall of the scale were correlating on the lower level. Notably, the item number 21 was not reliable, so we eliminated it. After the elimination of the item number 21, the Cronbach's Alpha coefficient for this test is $\alpha=0.603$, which is around what is considered to be approved or significant internal consistency and reliability. 


\section{RESULTS AND DISCUSSION}

The results from this research will be presented in two parts: Descriptive statistics and Correlation method. Also, the data will be presented both graphically and numerically.

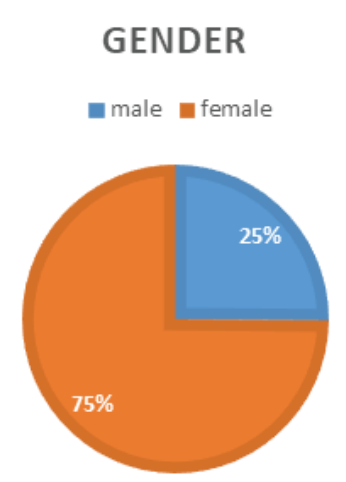

Fig. 4. The graphic representation of gender

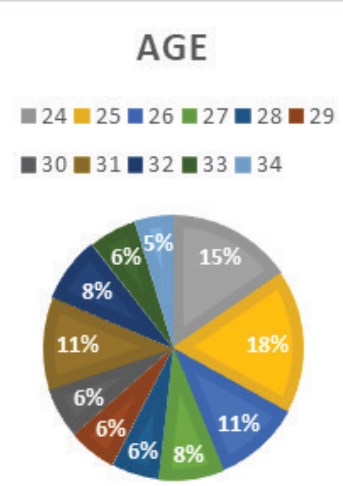

Fig. 5. The graphic representation of age

Table 1. Descriptive statistics for the tendencies towards psychosomatic reactions, coping styles and locus of control

\begin{tabular}{|c|c|c|c|c|c|c|c|}
\hline & z & $\Xi$ & $\stackrel{\text { ֻ }}{\Sigma}$ & $\Sigma$ & 㝏 & 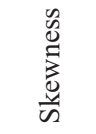 & 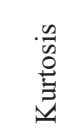 \\
\hline $\begin{array}{l}\text { Psycho- } \\
\text { somatics }\end{array}$ & 187 & 32 & 129 & 63.63 & 20.488 & 4.668 & 0.903 \\
\hline $\begin{array}{l}\text { Problem- } \\
\text { focused } \\
\text { coping }\end{array}$ & 187 & 15 & 35 & 27.46 & 4.384 & -2.179 & -0.590 \\
\hline $\begin{array}{l}\text { Emotion- } \\
\text { focused } \\
\text { coping }\end{array}$ & 187 & 7 & 35 & 23.41 & 5.988 & -1.443 & 0.903 \\
\hline $\begin{array}{l}\text { Avoidant } \\
\text { coping }\end{array}$ & 187 & 9 & 33 & 19.57 & 5.014 & 1.151 & 0.988 \\
\hline Coping & 187 & 43 & 95 & 70.44 & 8.650 & 0.314 & 1.245 \\
\hline $\begin{array}{l}\text { Locus } \\
\text { of control }\end{array}$ & 187 & 0 & 21 & 10.78 & 3.581 & * & * \\
\hline
\end{tabular}

The graphs presented above (Figure $4 \&$ Figure 5) are showing the characteristic of the research sample. As shown in Figure 6, the sample consists of 187 participants, out of whom we have 47 males and 140 females $(\mathrm{N}=187 ; \mathrm{Nm}=47$; $\mathrm{Nf}=140$ ). Figure 7 shows the percentage of the age of the participants that were involved in the research. The highest number of the participants is 33 (and those are 25 years old), whereas the lowest number of the participants is 9 (and those are 34 years old).

Table 1 presents descriptive statistics for variables psychosomatic tendencies, coping style and locus of control.

From the obtained results it is evident that the level of psychosomatic tendencies is pretty low. Keeping in mind the age-range of the participants, it is an excellent sign. Also, the most used coping style is emotion-focused coping, followed by the problem-focused coping style. The least used coping style is avoidant coping style. It is very appropriate, due to the fact that it is more problematic and serious than problem-focused and emotion-focused coping style. From the overall coping, it is apparent that it is active above the average. The locus of control shows that there are participants with total internal locus. The others are in the average, more prone to internal locus of control. This also counts into good results, pointing on the awareness of the personal control over the situations, which is appropriate with the agerange of the participants.

The graphic representation of descriptive statistics for tendencies towards psychosomatic reaction, coping styles and locus of control are presented on Figure 6.

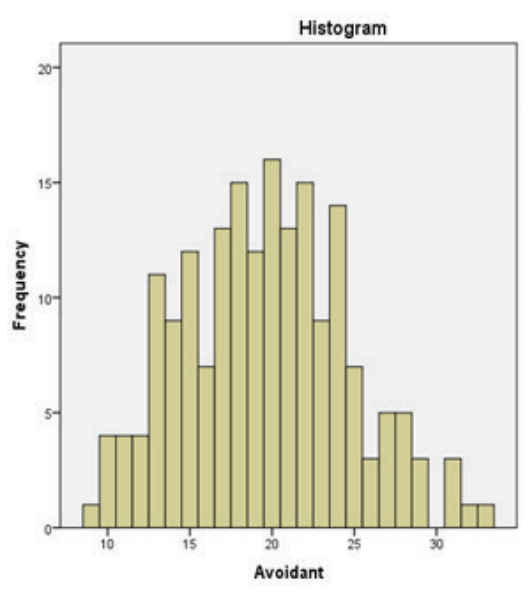



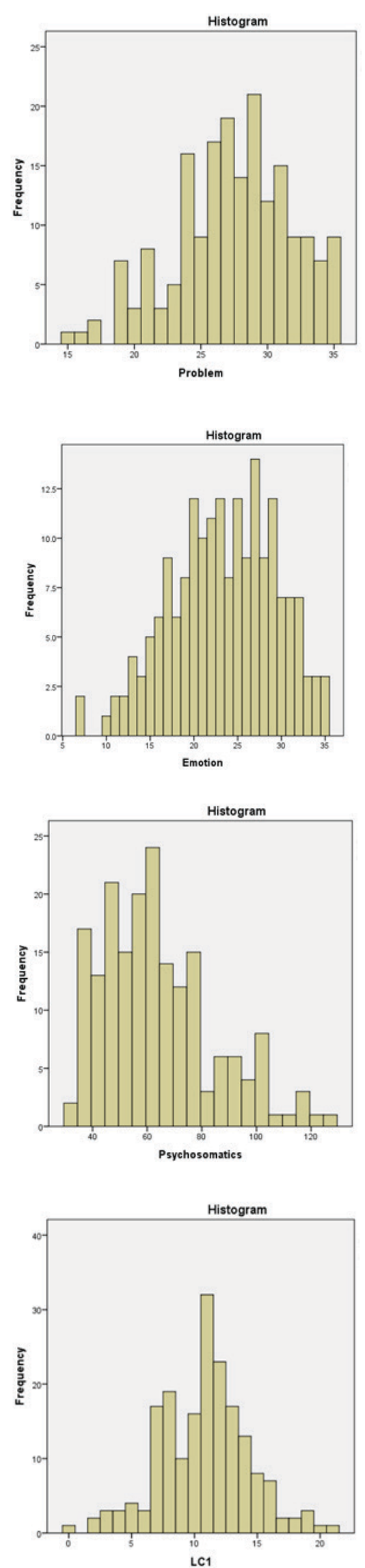

The coefficients of Spearman Correlation presented in Table 2 are presenting the correlation gained between all included variables.

\begin{tabular}{l}
\begin{tabular}{|l} 
Table 2. Spearman Correlation for the tendency to psycho- \\
somatic reactions, coping styles, locus of control and overall \\
coping
\end{tabular} \\
\hline \\
\end{tabular}

From the Table 2, we can see that there is a significant statistical correlation among all the variables, tendencies towards psychosomatic reactions, coping styles and locus of control. There is no correlation only among two variables. The avoidant coping style does not correlate neither with tendency towards psychosomatic reactions $(\mathrm{r}(187)=.032 ; \mathrm{p}>0.01)$, nor with the locus of control $(\mathrm{r}(187)=-.053 ; \mathrm{p}>0.01)$. Also, there is no correlation among overall coping and locus of control $(\mathrm{r}(187)=.104 ; \mathrm{p}>0.01)$. The negative correlation is among problem-focused coping and tendency towards psychosomatic reactions $(\mathrm{r}(187)=-.255 ; \mathrm{p}<0.01)$, and problemfocused coping and locus of control $(r(187)=-$ $-.211 ; \mathrm{p}<0.01)$. There is a strong correlation among emotion-focused coping and tendency to psychosomatic reactions $(\mathrm{r}(187)=.519 ; \mathrm{p}<0.01)$ and emotion-focused coping and locus of control $(\mathrm{r}(187)=.308 ; \mathrm{p}<0.01)$. Also, there is a correlation among tendency to psychosomatic reactions and locus of control $(\mathrm{r}(187)=0.310 ; \mathrm{p}<0.01)$. There is a correlation among overall coping and tendencies to psychosomatic reactions $(\mathrm{r}(187)=.304 ; \mathrm{p}<.01)$

Partial Correlation coefficient is calculated concerning gender and presented on Table 3.

Fig. 6. The graphic representation of descriptive statistics for tendencies towards psychosomatic reaction, coping styles and locus of control 
Table 3. Partial Correlation for the tendency to psychosomatic reactions, locus of control and coping styles having gender under control

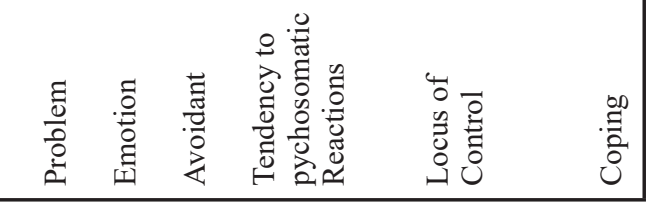

\begin{tabular}{|ccc|}
\hline Gender Problem & $.273^{* *}$ & $-.220^{* *}$ \\
\hline Emotion & $.588^{* *}$ & $.311^{* *}$ \\
\hline Avoidant & .059 & .036 \\
\hline $\begin{array}{l}\text { Tendency to } \\
\text { Psychosomatic } \\
\text { Reactions }\end{array}$ & & \\
\hline $\begin{array}{l}\text { Locus of } \\
\text { Control }\end{array}$ & $.254^{* * *} .304 * *$ \\
\hline Coping & & .126 \\
\hline$* \mathrm{p}<.01$ & & \\
\hline
\end{tabular}

From the Table 3, we can state the following:

- When we control gender in the relationship between the problem-focused coping style and tendency towards psychosomatic reactions, we have a positive correlation $(\mathrm{r}(187)=.273 ; \mathrm{p}<0.01)$, and with the locus of control we have the negative correlation $(r(187)=-.220 ; p<0.01)$.

- When we control gender in the relationship between the emotion-focused coping style and both tendency towards psychosomatic reactions and locus of control, we have a positive correlation $(\mathrm{r}$ $(187)=.588 ; \mathrm{p}<0.01 ; \mathrm{r}(187)=.311 ; \mathrm{p}<0.01)$.

- When we control gender in the relationship between the avoidant coping style and both tendency towards psychosomatic reactions and locus of control, we have no correlation ( $\mathrm{r}(187)=.059 ; \mathrm{p}>0.01$; $\mathrm{r}(187)=.036 ; \mathrm{p}>0.01)$.

-When we control gender in the relationship between the tendency towards psychosomatic reactions and both locus of control and overall coping, we have a positive correlation $(\mathrm{r}(187)=.254 ; \mathrm{p}<0.01$; $\mathrm{r}(187)=.304 ; \mathrm{p}<0.01)$.

- When we control gender in the relationship between the locus of control and overall coping, we have no correlation $(\mathrm{r}(187)=.126 ; \mathrm{p}>0.01)$.
Table 4. Spearman Correlation for the tendency to psychosomatic reactions and locus of control

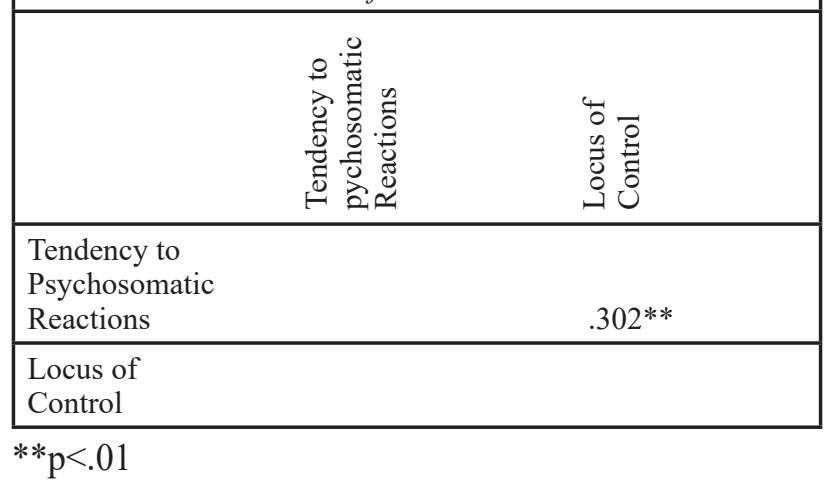

From the Table 4, we can read that there is a statistically significant positive correlation between the tendency to psychosomatic reactions and the locus of control $(\mathrm{r}(187)=.302 ; \mathrm{p}<0.01)$.

Table 5. Spearman Correlation for the coping styles and the tendency to psychosomatic reactions

\begin{tabular}{|c|c|c|c|c|}
\hline & $\begin{array}{l}\frac{1}{0} \\
\frac{0}{0} \\
0 \\
0\end{array}$ & 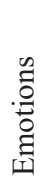 & 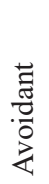 & 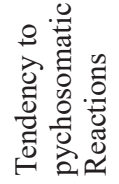 \\
\hline Problem & & & & $-.255 * *$ \\
\hline Emotion & & & & $.519 * *$ \\
\hline Avoidant & & & & .032 \\
\hline $\begin{array}{l}\text { Tendency to } \\
\text { Psychosomatic } \\
\text { Reactions }\end{array}$ & & & & \\
\hline
\end{tabular}

$* * \mathrm{p}<.01$

From Table 5, it is evident that there is statistically significant negative correlation among problem-focused coping style and tendency to psychosomatic reactions $((\mathrm{r}(187)=-.255 ; \mathrm{p}<0.01)$. There is a statistically significant positive correlation among emotion-focused coping style and tendency towards psychosomatic reactions $(\mathrm{r}(187)=.519 ; \mathrm{p}<0.01)$. There is no statistically significant difference among avoidant coping style and tendency towards psychosomatic symptoms $(\mathrm{r}(187)=.032 ; \mathrm{p}>0.01)$. 


\begin{tabular}{|c|c|c|c|c|}
\hline & $\begin{array}{l}\tilde{0} \\
\frac{0}{0} \\
0 \\
0\end{array}$ & 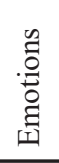 & 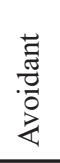 & 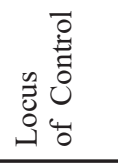 \\
\hline \begin{tabular}{|l|} 
Problem \\
\end{tabular} & & & & $-.211 * *$ \\
\hline Emotion & & & & $.308 * *$ \\
\hline Avoidant & & & & -.053 \\
\hline \begin{tabular}{|l} 
Locus \\
of Control
\end{tabular} & & & & \\
\hline
\end{tabular}

$* * \mathrm{p}<.01$

From Table 6, we can conclude that there is a statistically significant negative correlation between problem-focused coping style and locus of control ((r $(187)=-.211 ; \mathrm{p}<0.01)$. There is a statistically significant positive correlation between emotion-focused coping style and locus of control $((\mathrm{r}(187)=.308$; $\mathrm{p}<0.01)$. There no statistically significant correlation between avoidant coping style and locus of control $((\mathrm{r}(187)=-.053 ; \mathrm{p}>0.01)$.

Looking at the obtained results from this research, we can confirm the main hypothesis, that there is a significant connection between tendencies towards psychosomatic reactions, coping styles and locus of control in young adults in the Republic of North Macedonia. The Fig. 7 shows proposed own graphic interplay between psychosomatic tendencies, coping styles and locus of control.
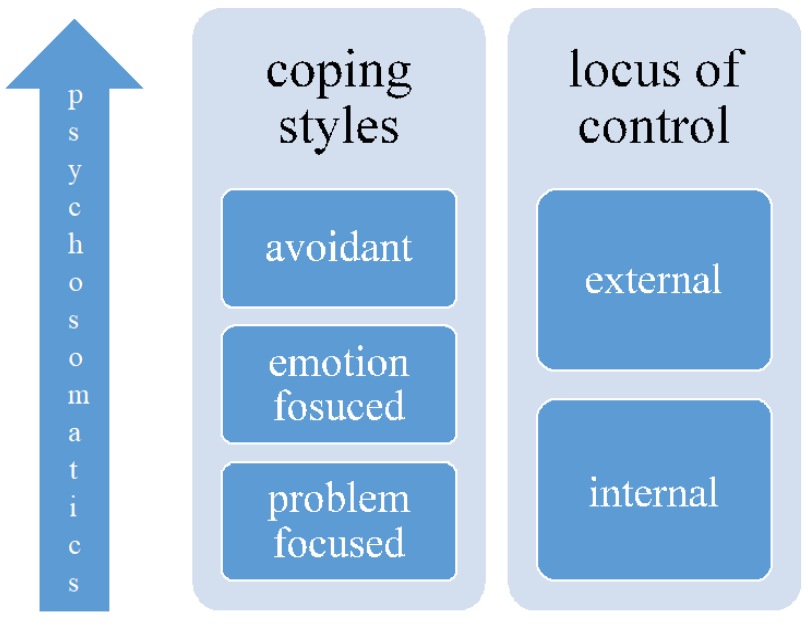

Fig. 7. The connection between psychosomatics, coping styles and locus of control

\section{CONCLUSION}

Psychosomatics can be defined as a continuum if perceived as having two poles: health and illness. If we connect it with the continuum of locus of control, internal locus of control would be in the healthy pole and external locus of control would be in the unhealthy pole. Further, connecting psychosomatics with stress, would put problem-focused coping in the healthy pole, and emotion-focused coping together with avoidant coping in the unhealthy pole. However, it is of great importance to note that neither one of the extremes is good. Neither one coping style being used all the time, neither one locus of control.

From the clinical perspective, the research could be expanded and its connectedness with severe mental disorders could be examined. The analysis of the difference between healthy and non-healthy population could be compared. Also, it could be investigated, how the locus of control influences the health beliefs and which role it has in the process of healing. Additionally, the preventive aspects could be inspected and analysed. Lastly, the environmental factors, such as air pollution, and their influence could be checked

\section{REFERENCES}

1. Adamovic, V. (1983). Emocije i telesne bolesti: uvod u teoriju i klinicku praksu psihosomatske medicine. Beograd: Nolit.

2. Adamovic, V. (2005). Psihosomatska medicina i konsultativna psihijatrija: prirucnik za klinicku praksu. Beograd: Sluzbeni list SCG

3. American Psychiatric Association. (2013). Diagnostic and statistical manual of mental disorders (5th ed.). Washington, DC.

4. Berger, J. \& Kostic, P. (2002). Bazicni oslonci licnosti i psiholoski potporni sistem. Belgrade: Drustvo Psihologa Srbije

5. Billings, A. G., \& Moos, R. H. (1984). Coping, stress, and social resources among adults with unipolar depression. Journal of Personality and Social Psychology, 46, 877-891. DOI: 10.1037/00223514.46.4.877

6. Cannon, W. (1932). Wisdom of the Body. United States: W.W. Norton \& Company.

7. Comer, R. J. (2015). Abnormal Psychology (9th ed.). New York, NY: Worth.

8. Endler, N. S., \& Parker, J. D. A. (1990). Multidimensional Assessment of Coping: A Critical Eval- 
uation. Journal of Personality and Social Psychology, 58, 844-854.

9. Ewen, R. B. (2003). An Introduction to Theories of Personality (6th ed.). New Jersey: Lawrence Erlbaum Associates, Inc., Publishers.

10. Friedman, H. S., \& Silver, R. C. (2007). Foundations of Health Psychology. New York, NY: Oxford University Press.

11. Harrington, A. (2008). The cure within: A history of mind-body medicine (1st ed). New York: W.W. Norton.

12. Lazarus, R. S., \& Folkman, S. (1984). Stress, appraisal, and coping (11. [print.]). New York: Springer.

13. Lefcourt, H. M. (Ed.). (1981a). Research with the locus of control construct. New York: Academic Press.

14. Lipowski ZJ. (1990) Is "organic" obsolete? , Psychosomatics 31(3):342-4.

15. Maack, D. J., Buchanan, E., \& Young, J. (2015). Development and Psychometric Investigation of an Inventory to Assess Fight, Flight, and Freeze Tendencies: The Fight, Flight, Freeze Questionnaire. Cognitive Behavior Therapy, 44(2), 117-127.

16. Momirović, K., Wolf, B. i Džamonja, Z. (1992). KON 6 - Kibernetička baterija konativnih testova. Beograd: Savez društva psihologa Srbije - Centar za primenjenu psihologiju.

17. Newman, B. M., \& Newman, P. R. (2012). Development through life: A psychosocial approach (11th ed). Belmont, CA: Wadsworth Cengage Learning.

18. Nowicki, S. (2016). Choice or chance: Understanding your locus of control and why it matters. Amherst, New York: Prometheus Books.

19. Nowicki, S., \& Duke, M. P. (2016a). Foundations of Locus of Control. In J. W. Reich \& F. J. Infurna (Eds.), Perceived Control (pp. 147-170).

20. O'Connor, D. B., Walker, S., Hendricx, H., Talbot, D., \& Schaefer, A. (2013). Stress-related thinking predicts the cortisol awakening response and somatic symptoms in healthy adults. Psychoneuroendocrinology, 438-446.

21. O'Connor, R. (2014). Undoing perpetual stress: The missing connection between depression, anxiety and 21 st century illness. Retrieved from ttp:// rbdigital.oneclickdigital.com

22. Ogden, J. (2007). Health psychology: A textbook (4. ed). Maidenhead: Open Univ. Press.

23. Rotter, J. (1966). Generalized Expectancies for Internal versus External Control of Reinforcement. Psychological Monographs: General and Applied, 80(1). Retrieved June 20, 2019.

24. Rotter's Locus of Control Scale. (n.d.). Retrieved March 20, 2019, from http://www.mccc.edu/ jenningh/Courses/documents/Rotter-locusofcontrolhandout.pdf

25. Straub, R. O. (2002). Health Psychology. New York: Worth Publishers.

26. 'World Health Organization. (2018). International statistical classification of diseases and related health problems (11th Revision). 


\title{
Резиме
}

\section{ПСИХОСОМАТСКИ ТЕНДЕНЦИИ, КОПИНГ-СТИЛ И ЛОКУС НА КОНТРОЛА КАЈ МЛАДИ АДУЛТИ}

\author{
Мелис Билибани ${ }^{1}$, Емилија Стоименова Цаневска ${ }^{1}$, Нада Поп-Јорданова ${ }^{2}$ \\ ${ }^{1}$ Меѓународен балкански универзитет, Скопје, РС Македонија \\ ${ }^{2}$ Македонска академија на науките и уметностите, Скопје, РС Македонија
}

Навистина е тешко да се живее во општество каде што секојдневно опаѓа хуманиот социјален контакт и каде што стресните ситуации стануваат неизбежни. Со цел да се биде здрав и да се има здрав животен стил, копинг-системот има голема улога.

Сведочејќи на ваква ситуација секојдневно, цел на оваа студија е да се истражи поврзаноста меѓу психосоматските тенденции, разните стилови на справување и локусот на контрола кај млади адулти, на возраст 24-34 години во Република Северна Македонија.

Испитуваниот примерок го сочинуваат 187 испитаници (47 машки и 140 женски) по случаен избор, кои прифатија да бидат дел од истражувањето пополнувајќи онлајн-прашалници поставени преку Гугл. Користен е кус демографски прашалник и три психолошки инструменти: Кибернетска батерија на конативни тестови (КОН-6), ЦИСС-21 (Прашалник за копинг при стресни ситуации) и Интерен-екстерен локус на контрола (Е-И скала). Добиените резултатите обработени статистички потврдија дека постои значајна корелација меѓу тенденциите за психосоматика, копинг-стилот и локусот на контрола кај младите адулти во РС Македонија

Клучни зборови: психосоматски симптоми, копинг, стрес, локус на контрола, млади адулти 